\title{
POLSKA I POLACY W OCZACH STUDENTÓW Z EUROPY PRZEBYWAJACYCH W LODZI W ROKU AKADEMICKIM 2015/2016 W RAMACH PROGRAMU ERASMUS+
}

SŁowa KLUCzowe: STEReOTyP POLAKa, Erasmus+, MOBILność STUdentów, ŁóDŹ

\section{WPROWADZENIE}

Erasmus + to program uruchomiony w 2014 roku, zastępujący wszystkie dotychczasowe projekty podlegające pod program „Uczenie się przez całe życie”. Inicjatywa przeznaczona jest dla studentów i pracowników naukowych szkół wyższych, pod warunkiem, iż ci ostatni posiadają Kartę Erasmusa dla Szkolnictwa Wyższego. Udział w projekcie deklaruje obecnie ponad dwa tysiące uczelni w Europie, w tym czołowe polskie uniwersytety. Nadzór nad projektem w Polsce sprawuje Fundacja Rozwoju Systemu Edukacji. Komisja Europejska przeznaczyła na realizację programu (lata 2014-2020) budżet sięgający 16,8 mld euro.

Wymiana studentów i pracowników naukowych zaczyna się we wrześniu (semestr zimowy) i w lutym (semestr letni). Sama decyzja o wzięciu udziału w projekcie musi być podjęta znacznie wcześniej, np. zapisy na semestr zimowy (wymiana we wrześniu) ruszają w lutym. Wówczas kandydaci dokonują wyboru uczelni i miasta, gdzie w przyszłości będą kontynuować studia. Istotną rolą w procesie rekrutacji jest znajomość języka obcego (w większości wypadków jest to język angielski), który powinien być co najmniej na poziomie B1. Dobrze znać również podstawy języka kraju, do którego się wybieramy, np. niektóre uczelnie we Francji zastrzegają sobie znajomość języka francuskiego na poziomie podstawowym, by ich studenci mogli komunikować się w języku docelowym. Często uczelnie partnerskie oferują także dodatkowe kursy dla osób chcących nauczyć się języka obowiązującego w danym kraju. Zajęcia te rozpoczynają się zazwyczaj dwa tygodnie przed początkiem zajęć na uczelni. Kursy językowe można kontynuować przez cały czas trwania Erasmusa. 
Wyjazd w ramach programu Erasmus+ może trwać od trzech miesięcy do jednego roku. Każdej podróży towarzyszy dofinansowanie, przeznaczone z góry, w kwocie zależnej od państwa, w którym podjęto studia. Jak sama nazwa wskazuje, dofinansowanie pokrywa jedynie część kosztów związanych z pobytem, resztę studenci muszą zdobyć we własnym zakresie. Studenci programu Erasmus+ są zobowiązani do realizowania planu zajęć zgodnego z ich przedmiotami kierunkowymi i objętego adekwatną sumą punktów ECTS [http://erasmusplus.org.pl/o-programie].

\section{UCZESTNICY BADANIA}

Grupa badawcza składała się ze studentów będących uczestnikami programu Erasmus+ w roku akademickim 2015/2016. Pod uwagę zostali wzięci studenci Uniwersytetu Łódzkiego, łącznie badana grupa stanowiła 25 uczestników, wśród których znaleźli się Hiszpanie, Kolumbijczycy, Ukraińcy, Francuzi, Grecy, Portugalczycy, Włosi oraz mieszkańcy Kurdystanu.

Ze względu na nieznajomość języka polskiego (tylko 3 respondentów z 25 badanych wyraziło chęć nauki języka polskiego w zorganizowanym przed studiami dwutygodniowym podstawowym kursie języka polskiego) postanowiono przeprowadzić ankiety w języku angielskim. Wszyscy studenci objęci badaniem uczęszczali na zajęcia z zakresu filologii angielskiej, poziom ww. języka widniejący na dokumentach, które dostarczyli, wahał się od B1 do C1. Dla 20 osób spośród 25 uczestników badania język angielski był pierwszym językiem obcym, dla pozostałych 5 osób język angielski był drugim językiem obcym zaraz po języku rosyjskim i arabskim, jednakże wskazani respondenci posługiwali się nim z dużą biegłością.

\section{BADANIE I JEGO PRZEBIEG}

Celem badania była odpowiedź na pytanie o obraz Polski i Polaka w oczach studentów zagranicznych uczelni przyjeżdżających na wymianę do Łodzi. Autorka pragnęła sprawdzić, jaką wiedzę na temat docelowego kraju posiadają Erasmusi i czy posiadane informacje pokrywają się z aktualnym, rzeczywistym stanem.

Badanie zostało przeprowadzone $\mathrm{w}$ trakcie semestru letniego roku akademickiego 2015/2016 podczas jednych zajęć metodycznych, wypełnienie ankiety trwało około 15 minut.

Każdy z uczestników badania otrzymał dwie anonimowe ankiety, zawierające łącznie pięć pytań otwartych. Pierwsza ankieta zakładała odpowiedź na pytanie, jacy według badanych są Polacy. W drugiej ankiecie respondenci zostali poproszeni o wymienienie kolejno trzech polskich miast (za wyjątkiem Łodzi), trzech sławnych Polaków, trzech polskich słów i trzech nazw polskich potraw.

Uczestnicy badania, realizujący program właściwy filologii angielskiej, wypełniali ankietę w języku, który studiowali w Polsce, tj. w języku angielskim. 


\section{KILKa SLÓW O STEREOTYPACH}

Słowo stereotyp wywodzi się z połączenia dwóch greckich słów, stereós - mocny, stabilny, trwały i typos oznaczający obraz, model, wrażenie. Po raz pierwszy pojęcie to pojawiło się na łamach książki W. Lippmanna Public Opinion. Autor zdefiniował stereotyp jako „obraz w głowie ludzkiej” [Lippmann 1961: 3], przy czym zaznaczył podwójną funkcję tego pojęcia: psychiczną opierającą się na ekonomizacji wysiłku jednostki w poznawaniu świata oraz społeczną definiowaną jako „obronę szeroko rozumianej pozycji społecznej” [Bartmiński 1985: 23]. O funkcji społecznej szerzej pisał J. Chałasiński: „Stereotypy te (społeczne) to są definicje ludzi, przedmiotów, stosunków i sytuacji, których dokonujemy na każdym kroku i które przekazuje tradycja społeczna. Nie są one wynikiem logicznego rozumowania, lecz wynikiem doświadczenia, w którym dominującą rolę odgrywają procesy instynktowe. Niemniej one to właśnie składają się na najważniejszy dla nas świat znaczeń, który nazywamy rzeczywistością społeczną" [Chałasiński 1935: 48].

Inaczej stereotypy społeczne charakteryzuje B. Weigl; autorka wyróżnia szereg kryteriów wyróżniających pojęcie. Stereotypy społeczne rozpatrywane jako schematy kategorialne będą cechowały się nadmiernymi uproszczeniami, wartościowaniem cech, generalizacją, silnym przekonaniem o podobieństwach pomiędzy jednostkami reprezentującymi daną grupę oraz znikomą podatnością na modyfikacje [Strelau 2005: 206]. Ponadto w stereotypach pojawią się obrazy uproszczone, znikoma bądź słaba wiedza na dany temat, ideologia jednostkowa i subiektywizm. Brakować będzie w nich korekty informacji bądź zapotrzebowania na jej weryfikację i ocenę [Pospiszyl 2008: 51].

Jak zauważa J. Bartmiński, prace socjologiczne rozwijające koncepcję Lippmanna znacznie zawężają perspektywy badawcze i akcentują głównie fakt odniesienia stereotypu do zachowań człowieka i kształtowania przez nie pewnego obrazu rzeczywistości społecznej [Bartmiński 1985: 27].

Dlatego też w niniejszym artykule chciałabym zaprezentować również lingwistyczny podział stereotypów zaprezentowany przez W. Chlebdę. Jak pisze autor, stereotyp możemy sprowadzić do trzech podstawowych ujęć: 1) stereotyp jest reprodukowanym związkiem wyrazowym (stereotyp lingwalny), 2) stereotyp jest specyficznym konstruktem mentalnym (stereotyp mentalny), 3) stereotyp jest specyficznym konstruktem mentalnym zakorzenionym w świadomości jako znak językowy (stereotyp lingwomentalny) [Chlebda 1998: 32].

W literaturze przedmiotu stereotypy jako pojęcia znaczeniowe traktowane są dwubiegunowo. Część opracowań traktuje je jako przeciwieństwo dla pojęć opiswartościowanie, z kolei reszta traktuje je jako opozycję jednostki do grupy. Pierwsza koncepcja, tj. opis deskryptywny zakłada, że stereotyp to charakterystyka jakiejś grupy, która ujawnia się w pamięci jednostki na podstawie skojarzenia $\mathrm{z}$ daną kategorią, zatem nazwa kategorii w sposób automatyczny będzie wpływała na treść reprezentacji. Opis ten tłumaczy łatwą akwizycję stereotypów, postępowanie schematowe i szybką identyfikację pojęć, nie ocenia natomiast wpływu uczuć i emocji 
na reprezentacje stereotypów ${ }^{1}$. Opis ewaluatywny znajdujący się również w ujęciu pierwszym zwraca uwagę na aspekt emocjonalny. Głosi bowiem, iż stereotypy oprócz treści zawierają również ocenę. Na tej podstawie możemy stwierdzić, iż wartościowanie jest składnikiem immanentnym pojęcia stereotyp, zatem aktywizacja stereotypu będzie automatycznie wzbudzała aktywizację oceny danej kategorii bądź grupy $^{2}$. Druga koncepcja zawiera w sobie podejście społeczno-poznawcze i podejście kulturowe. Pierwsze z nich zakłada, iż stereotyp jest rezultatem doświadczenia jednostki poprzez kontakt $\mathrm{z}$ danymi kategoriami i grupami społecznymi którego doznała. Opis ten sugeruje, iż stereotypy są podatne na zmiany i modyfikacje, gdyż jednostka stale doświadcza nowych rzeczy, weryfikując swoje poprzednie poglądy. W tym miejscu warto przywołać klasyfikację C. Stangora i M. Schallera, którzy wyróżniają trzy podejścia indywidualistyczne: 1) schemat grupowy - jednostka jest przekonana o tym, iż cechy jednego członka grupy są charakterystyczne dla całej grupy, do której owa jednostka przynależy; 2) prototyp grupowy - określenie cech grupy na podstawie cech jednostki, jednak z zastosowaniem mniejszej generalizacji cech; 3) egzemplarz - koncentrowanie uwagi na wybranej jednostce jako reprezentancie cech i wartości reprezentowanych przez grupę [Stangor, Schaller 1999]. Drugie podejście, kulturowe, odwołuje się do społeczeństwa i podzielanych przez nie wartości. W tym ujęciu stereotypem będzie wiedza zbiorowa przekazywana i transmitowana w obrębie danej społeczności.

Na podstawie powyższych definicji możemy stwierdzić, iż stereotypy towarzyszą nam już od najmłodszych lat. Genezą ich powstania mogą być doświadczenia społeczne lub indywidualne, często noszące znamiona dość dużego ładunku emocjonalnego. Jeśli chodzi o opinie indywidualne, wpływają na nie cechy umysłu, tj. szerokość kategorii poznawczej i iluzoryczność korelacyjna. T. F. Pettigrew wykazuje, iż pewne jednostki posiadają tendencję do uogólniania i generalizowania, nie dostrzegają więc dużej różnorodności pomiędzy wybranymi egzemplarzami, inne z kolei wychwytują od razu rozbieżności i różnorodność w obrębie kategorii. Według badacza fakt ten jest spowodowany ukształtowaniem ludzkiego umysłu [Pettigrew 1970]. Zjawisko iluzorycznej korelacji to potoczna koncepcja współwystępowania danych cech u osób bądź grup, które w rzeczywistości nie mają cech wspólnych bądź skupienie uwagi na celach wyrazistych, odbiegających od utartego wzorca [Strelau 2005].

W kształtowaniu stereotypów dużą rolę odgrywa społeczność, w której jednostka dorasta, pewne normy i wartości kultywowane są w jej najbliższym kręgu. Rodzice w pierwszej kolejności wpływają na postrzeganie świata przez swoje potomstwo. Liczne badania amerykańskich naukowców udowodniły, iż stereotypy, w które wierzą rodzice są przekazywane dzieciom, a te przyjmują je jako naturalne i zaczynają się z nimi utożsamiać [Fagot, Leinbach, O’Boyle 1992]. Istotną rolę pełnią również media i czasopisma propagujące pewne wzory i narzucające postrzeganie świata.

\footnotetext{
${ }^{1}$ Więcej na temat opisu deskryptywnego przeczytać można w pracy [Kurcz 1994].

${ }^{2}$ Więcej na temat przeczytać można w [Dovidio, Gaertner 1986].
} 


\section{UZYSKANE WYNIKI}

Jak wspomniano wcześniej, respondenci otrzymali dwie ankiety. Pierwsza z nich dotyczyła wizerunku Polaków; badani mieli napisać, co sądzą na ich temat. W większości odpowiedzi można było doszukać się pozytywnych rzeczy. Erasmusi podkreślali, iż Polacy, których spotkali, byli dla nich pomocni oraz odpowiadali na liczne pytania dotyczące drogi na uczelnię czy do akademika. W opisach często padało słowo mentor - jest to polski student opiekujący się Erasmusem przebywającym na wymianie - według badanych dzięki pomocy mentora Erasmusi czuli się pewnie, gdyż wiedzieli, że zawsze mogą się zwrócić do kogoś o pomoc, z czego chętnie korzystali. Kolejne cechy określające Polaków to towarzyscy, mili, gościnni. Respondenci powoływali się tu na współmieszkańców akademików, panie z recepcji (pomoc przy kwaterowaniu, opłatach za domy studenckie) oraz przypadkowe osoby poznane np. w tramwaju (pomoc w tłumaczeniu kierunku jazdy). Jeśli chodzi o negatywne cechy, badani wskazywali na zbytnią punktualność (szczególnie widoczne jest to w ankietach osób hiszpańsko oraz włoskojęzycznych) i brak dostatecznej znajomości języka angielskiego. W jednej ankiecie respondent wspomniał, iż w momencie użycia języka ojczystego spotkał się z negatywną reakcją współpasażera w tramwaju, który wyjaśnił mu, iż skoro jest w Polsce, powinien mówić w języku polskim.

Druga ankieta dotyczyła wiedzy na temat Polski. Erasmusi zostali poproszeni o wymienienie trzech polskich miast ( $\mathrm{z}$ wyjątkiem Łodzi), trzech sławnych Polaków, trzech polskich słów i trzech nazw polskich potraw. Mówiąc o miastach, najwięcej wskazań otrzymał Kraków (23 odpowiedzi), za nim uplasowały się Gdańsk (19) i Warszawa (17). Czternastu ankietowanych wymieniło Wrocław, dwoje podało Toruń. Wymienienie trójki sławnych Polaków sprawiło badanym duży problem, żaden z respondentów nie podał trzech odpowiedzi, w większości przypadków pojawiła się jedna odpowiedź - Robert Lewandowski, kilkoro respondentów wspomniało o Janie Pawle II. Polskie słowa okazały się najbardziej liczną kategorią odpowiedzi, Erasmusi zwykle wpisywali więcej niż 3 wyrazy, najczęściej pojawiającymi się leksemami/wyrażeniami były: cześć; halo; tak, tak; dzień dobry; piwo; dziękuję; dziękuję bardzo; proszę; nie mówię po polsku; nie rozumiem; dobrze; nie, nie. W ankietach nie zabrakło również polskiego przekleństwa „kurwa”, które pojawiło się niemal w każdej pracy (wyjątek stanowiła tu jedna ankieta). Ostatnie pytanie dotyczyło polskich potraw, najwięcej głosów zdobyły pierogi, które zostały wskazane przez wszystkich respondentów. Następnie w kolejności pojawiły się naleśniki (21 odpowiedzi) i zupa (13 wskazań). Część respondentów ograniczyła się jedynie do podania jednej bądź dwóch odpowiedzi.

\section{KWESTIE PROBLEMATYCZNE}

W badaniu wzięła udział ograniczona grupa Erasmusów, nie jest ona zatem wystarczającą ilością respondentów, by móc wysunąć ogólne wnioski nt wyników. W celu uzyskania większej ilości informacji można by się było pokusić o zebranie identycznych danych w innych miastach akademickich (np. Warszawa, Kraków, Wrocław itp.), a następnie można by skorelować te wyniki z odpowiedziami uzyskanymi z łódzkich ankiet. Dzięki temu obserwacja wizerunku Polski i Polaków byłaby 
pełniejsza. Niemniej jednak powyższe badanie można potraktować jako badanie pilotażowe służące zapoznaniu się z opiniami na temat Polski i Polaków. Ze względu na fakt powszechnej mobilności, braku granic i dużej popularności programu Erasmus+, kwestia dalszych badań w zakresie obrazu Polski i Polaków w oczach innych narodowości jawi się jako kwestia otwarta, wymagająca dalszych rozważań.

\section{ZAKOŃCZENIE}

Program wymiany międzynarodowej wciąż przyciąga nowych studentów chcących wyjechać na studia do innego kraju. Rokrocznie do Łodzi przyjeżdża około 1000 Erasmusów, z których większość decyduje się na studia tylko w jednym semestrze, tj. zimowym lub letnim. Istnieje jednak spora grupa pozostająca w Polsce przez cały rok akademicki. Jak pokazało badanie pilotażowe, respondenci dysponują wiedzą z zakresu państwa, do którego trafiają na Erasmusa, czasem jest to wiedza obszerniejsza (jak w przypadku polskich słów czy miast), czasem badani zdają się mieć trudności z odpowiedzią na pytania, choć i tu pojawiają się trafne sugestie. Jak wspomniano powyżej, badanie pilotażowe spełniło swoje zadanie, ukazując szkic obrazu Polski i Polaka w oczach studentów zagranicznych przebywających w Łodzi na wymianie międzynarodowej. Jak zasugerowano, kolejnym etapem może być powtórzenie niniejszego badania na większą skalę.

\section{BibliografiA}

BARTMIŃSKi J. [1985], Stereotyp jako przedmiot lingwistyki (cz.1), [w:] Z problemów frazeologii polskiej i stowiańskiej III, Basaj M., Rytel D. (red.), Wrocław.

Chatasiński J. [1935], Antagonizm polsko-niemiecki w osadzie fabrycznej „Kolonia" na Górnym Ślasku, Warszawa.

ChlebDa W. [1998], Stereotyp jako jedność języka, myślenia i działania, [w:] Anusiewicz J., Bartmiński J. (red.), Stereotyp jako przedmiot lingwistyki. Teoria, metodologia, analizy empiryczne, Towarzystwo Przyjaciół Polonistyki Wrocławskiej, Wrocław.

Dovidio L., Gaertner J. [1986], Prejudice, discrimination, and racism, San Diego, US.

Fagot B., Leinbach M., O’Boyle Ch. [1992], Gender labeling, gender stereotyping, and parenting behaviors, [w:] Developmental Psychology, Vol. 28(2).

Kurcz I. [1994], Zmienność i nieuchronność stereotypów, IP PAN, Warszawa.

Lippmann W. [1961], Public Opinion, New York.

Pettigrew T. F. [1970], Eye dominance in the visual cortex, [w:] Nature, nr 225, London.

Pospiszyl I. [2008], Patologie spoleczne, Wydawnictwo Naukowe PWN, Warszawa.

Stangor C., Schaller M. [1999], Stereotypy jako reprezentacje indywidualne i zbiorowe, [w:] Stereotypy i uprzedzenia, Macrae C., Stangor Ch., Hewstone M. (red.), GWP, Gdańsk.

Strelau J. [2005], Psychologia. Podręcznik akademicki. Tom III, Gdańskie Wydawnictwo Psychologiczne, Gdańsk.

http://erasmusplus.org.pl/o-programie [dostęp: 20.09.2015]. 